\title{
The Present Situation, Problems and Countermeasures of the Exhibition Industry in Guangdong, China
}

\author{
Xin Lu', ${ }^{1,2}$ Miao Ouyang1,2 \\ ${ }^{1}$ Accounting Management School, Jinan University, Guangzhou, China \\ ${ }^{2}$ School of Management, Jinan University, Guangzhou, China \\ Email: 1205647328@qq.com
}

Received 8 August 2016; accepted 29 August 2016; published 1 September 2016

Copyright (C 2016 by authors and Scientific Research Publishing Inc.

This work is licensed under the Creative Commons Attribution International License (CC BY). http://creativecommons.org/licenses/by/4.0/

(c) () Open Access

\begin{abstract}
As a kind of high efficiency, no pollution and with extremely strong industrial power to related industries, people pay more attention to the exhibition industry now. At present, exhibition industry of China is in a high-speed developmental period, and the International Convention and Exhibition Center is transferring to Chinese. As an economic strong province in China, Guangdong has ushered in a golden opportunity on exhibition industry, but it also faces great challenges. This mainly refers to the low level of informationization, specialization, marketization, the awful service quality, the lack of talents etc. This paper compares the exhibition's situation of Guangdong province to that of other provinces, in order to find out the problem, and promote faster and better development of the exhibition industry in Guangdong.
\end{abstract}

\section{Keywords}

Exhibition, Present Situation, Problems and Countermeasures

\section{Introduction}

According to the statistics of CCPIT (the China Council for the Promotion of International Trade) in 2014, the number of exhibition in ten best exhibition provinces of China was a total of 1694 projects. In the view of the acreage of exhibition venue, China has 7 million and 900 thousand square meters exhibition areas in total. But among them, the ultra large exhibition venue which available exhibition area reached 100 thousand square meters just accounted for $16.37 \%$, and the small venues which available exhibition area reached just 20 thousand square meters accounted for $31 \%$, which shows that the exhibition industry is rapidly developing and that China 
faces the problem of the imbalance distribution of exhibition venues [1].

In the aspect of provinces, the provinces which available exhibition area was 1 million or more were a total of 14, with a total exhibition area of 55 million and 10 thousand square meters. It is worth mentioning that the exhibition area in Guangdong is 17 million 170 thousand square meters and the number of projects is 542 in total, which ranked first in China. But it is worth pointing out that there are some deficiencies as well. This article will elaborate from the exhibition scale and exhibition venues on the current situation of Guangdong, and at last, point out the problems and give the corresponding development countermeasures.

\section{Present Situation of Exhibition Industry in Guangdong}

\subsection{Number and Size of Exhibition}

Guangdong held a total of 542 exhibition projects in 2014, with a total exhibition area of 17 million 170 thousand square meters, but mainly concentrated in Guangzhou and Shenzhen. Guangzhou had 259 exhibition projects, with a total exhibition's area of 9 million and 230 thousand square meters, accounting for $52.76 \%$ of the province's total and Shenzhen had 89 projects, the total exhibition's area of 3 million and 120 thousand square meters. From the point of structure, more than 100 thousand square meters of the exhibition were a total of 31, with a total exhibition's area of 8 million and 630 thousand square meters; 50 - 100 thousand square meters of the exhibition were a total of 38, with a total exhibition's area of 2 million and 580 thousand square meters.

From the point view of the seasonal distribution, Guangzhou's exhibition mainly concentrated in the first half of the March, May, June and the second half of October, November and December, and most exhibition lasted 3 days, accounted for $52.91 \%$. In addition, the industry is widely distributed in the exhibition of Guangdong, where Home building materials, automobile transportation and food of the exhibition were 195 together, ranked first, second and forth respectively.

In comparison, Beijing held a total of 258 exhibition projects in 2014, with a total exhibition's area of 7 million and 250 thousand square meters. According to the report of joint developmental association of Beijing exhibition's industry, the total revenue of exhibition's industry was nearly 23 billion yuan in 2013. Among them, the conference revenue was about 12 billion yuan (last year was 19 billion and 987 million yuan), the exhibition's revenue was about 9 billion and 700 million yuan, reward tourism revenue was nearly 1 billion yuan (up $20 \%$ over last year), an increase of more than $20 \%$. While in 2013, Shanghai held a total of 361 exhibitions, but the total exhibition's area was 11 million and 200 thousand square meters [2]. Only in 2010, Shanghai held a total of 448 domestic and international exhibition's projects, with a total exhibition's area of about 8,000,000 square meters, International exhibition 227, exhibition's area of 5 million and 800 thousand square meters. The total exhibition's area would be more than 15 million square meters in 2015. Obviously, the number of exhibitions in Shanghai had declined, but its exhibition's area was showing a rising trend, which showed that Shanghai was in the direction of the development of large and medium-sized exhibition's project [3].

In summary, we can see that exhibition's area of Guangdong province and the number of projects were higher than those of Shanghai, Beijing. But compared to Shanghai, the large and medium-sized exhibition was less than $6 \%$ of the total number of projects of the province exhibition's project.

\subsection{The Situation of Exhibition Organizer}

The exhibition's enterprises have more than 4 thousand in Guangdong, 31 exhibition's venues, accounting for $13.78 \%$ of the country. However, the majority was small and medium sized venues, accounting for about $71 \%$ of all venues, its exhibition's area of 1 million and 549 thousand square meters. Its market was more than 100 enterprises in Guangdong Province and the exhibition's market is huge which has good development potential.

\section{The Problem of Exhibition Industry in Guangdong Province}

\subsection{Low Market Level and Association Driven Effect Is Not Obvious}

Exhibition's industry is an industry with strong correlation, such as the Guangzhou Fair [4], the ratio of the input and the related industry output value was 1:10. But the organizers of exhibition put most of the time and energy into solving the exhibitors' food, housing, travelling and so on which should be able to undertake the affairs of 
the tourism sector. As a result, it caused the relative lag of the supporting services and was not conducive to the upgrading of clusters. In addition, the requirements of the cluster network collaboration and brand innovation was not in place, causing cluster effect of industry of Guangdong's exhibition not obvious.

\subsection{Low Market Level}

\subsubsection{Market Mechanism Is Not Perfect}

Government's intervention in the exhibition's market was too much, lack of guidance on the exhibition, which hindered the development of the market of exhibition's industry. The supply and demand mechanism, price mechanism, industry self-regulatory mechanism and competition mechanism of the exhibition's market have not really played a role, dependence on government's investment funds in a long time, and there is no forming mechanism of a self-financing.

\subsubsection{Market's Information Is Asymmetry}

The channel of exhibition's information is not smooth, resulting organizers and exhibitors could not communicate effectively, as a result exhibition could not reach the expected results, and even appeared to cheat, false exhibition and so on, disrupted the market's order of the exhibition in a certain extent.

\subsection{Low Service Quality}

Exhibition industry belongs to the quality of service, so the is the key factor for the development of exhibition's industry. At present, Guangdong is lack of specialized division of labor, professional service not strong, the level of green not high, the quality not high. Venues exhibition's area is not large enough, and function is single, and supporting hardware facilities are not complete, leading to the inadequate utilization of venues and waste of resources.

\subsection{Low Level of Information}

The information structure of exhibition's enterprise mainly includes the information structure of the trinity of office information, field management information and exhibition's network information. With the popularity of the Internet and the development of information technology, the level of information technology in the exhibition's industry is constantly improving. In developed countries in Europe and the United States, information technology is widely used in the exhibition industry, which greatly improves the management efficiency and service quality of the exhibition. In contrast, the exhibition's industry of Guangdong is still relatively low degree of information technology, and information technology in the exhibition's industry in the application is more backward.

\subsection{Lack of Talent}

Every year exhibition held up to dozens of games in Guangzhou, and only registered on 2008 was as high as 370 field exhibition which showed that the talent demand of exhibition was larger. In 2006, the demand for professional talents of exhibition was about 8000 people, and the demand for professional talents of exhibition reached about 100 thousand people during the 2010 Asian Games.

In addition, the exhibition's practitioners are not professionals, personnel mobility is large, the phenomenon of professional level is not high, Guangzhou as the third exhibition city in China, it is in urgent need of creative, management, professional and technical type of exhibition talents. The education and training of exhibition in China is far behind the pace of development of the exhibition industry, resulting in shortage of talent.

\section{Countermeasures on the Development of Exhibition Industry in Guangzhou}

\subsection{Improve the Professional Level}

According to the province's industrial base and regional advantages of reasonable development of the province's exhibition's industry objectives to make the goal of industry of the province's exhibition and construct the corresponding infrastructure to clear the theme of the development of industry of exhibition in the country and the region, to grasp the trend of world economic development and organize professional theme exhibition. Or- 
ganize market research and design exhibition according to the market demand, and clear the theme of the exhibition.

Carefully carry out the marketing plan, set up service consciousness and brand consciousness, and learn and draw lessons from the advanced management methods and market operation experience of famous foreign exhibition's enterprises. Accelerate the construction of our own brand and establish our own image, improve the enterprise and exhibitions international famous degree, reputation and industry recognition.

\subsection{Improve the Market Mechanism}

Speeding up the marketization of industry of exhibition is the direction of the future development of China's industry of exhibition. In order to achieve the optimal allocation of resources, maximize the benefits, cost savings, it should establish an equal and efficient market mechanism as soon as possible, and against unfair competition and fraud to create a good market environment and fair competition order and really push the industry of exhibition to the market. If carry out severe market access system, improve the industry threshold, speed up the development of exhibition, improve the overall quality of exhibition, it would realize the diversification of the market players, give full play to the role of the main market.

\subsection{Improve Service Quality}

Exhibition's enterprises and venues should enhance the service quality of the exhibition to provide high quality caring, full range, humanization, intelligent one-stop service, as a result, it would maximize the convenience of customers, and cultivate loyal customers. In order to achieve this goal, we must develop the service outsourcing business of exhibition in our country as soon as possible to improve the degree of professional service of outsourcing market so that it could ensure the quality of the exhibition outsourcing services.

Accelerate the development of the downstream industry of industry chain to form a complete set of service system as soon as possible. The construction of the venue should have scientific plan, not only to look at the number but also look at the scale, quality, and look at the venues in the industry's influence, status and reputation. Pay attention to the selection and quality of the site design, equipped with first-class facilities exhibition, such as the pavilion exhibition area, ventilation, water, electricity and communication which should reach the degree of standardization. It should be equipped with green leisure venues and parking to provide convenient services for the exhibitors and professional visitors outside the museum.

\subsection{Promote the Development of the Information Process}

At present, China's exhibition's enterprises should change their ideas as soon as possible, and pay attention to the information construction of the exhibition's industry, and actively take measures to promote the development of the exhibition's industry's information process in order to improve the management efficiency and service quality of the exhibition's industry. In this process, the application of information technology in the exhibition's industry is the key. As the exhibition's enterprises, they must pay special attention to information technology during the promotion, sales management and follow-up of customer.

\subsection{Strengthening the Cultivation and Introduction of Talents}

Exhibition's enterprises and venues should enhance the service quality of the exhibition to provide high quality caring, full range, humanization, intelligent one-stop service, as a result, it would maximize the convenience of customers, and cultivate loyal customers. In order to achieve this goal, we must develop the service outsourcing business of exhibition in our country as soon as possible to improve the degree of professional service of outsourcing market so that it could ensure the quality of the exhibition outsourcing services.

\section{Conclusion}

According to the relevant data of 2014, we described the number, exhibition area and Exhibition Industry distribution and other relevant information of Guangdong, and compared it with the domestic situation of the relevant provinces. It is found that there are specialization, marketization, low level of information, low service quality and the backward management mode in Guangdong exhibition industry. We put forward advices to solve 
the problems, such as improving the professional level, the market mechanism, and service quality, hoping a further development of exhibition industry in Guangdong.

\section{Funding}

National Natural Science Fund Project "the distributed data consistency and XBRL network financial reporting quality control” 71171097; Jinan University Enterprise Development on the major projects "transformation of enterprises in strategic cost management research" 2014ZD001.

\section{References}

[1] Guangdong Council for the Promotion of International Trade. http://www.gdefair.com/special/exhibition/index.asp?tid=198\&nid=1154

[2] Liu, D.K. (2013) Chinese Exhibition Industry: Theory, Current Situation and Policy. China Business Press, Beijing, 235-236.

[3] Gong, W.G. and Yang, S.Y. (2013) Shanghai Exhibition Industry Development Report. China Literature Press, Beijing, 100-102.

[4] Zhou, Z.Z. (2010) The Present Situation and Development Countermeasure of the Exhibition Industry in Guangzhou. Journal of Shaoguan University Social Science, 31, 104-107. http://wenku.baidu.com/view/bfa714cdda38376baf1faecc.html

\section{Submit or recommend next manuscript to SCIRP and we will provide best service for you:}

Accepting pre-submission inquiries through Email, Facebook, LinkedIn, Twitter, etc.

A wide selection of journals (inclusive of 9 subjects, more than 200 journals)

Providing 24-hour high-quality service

User-friendly online submission system

Fair and swift peer-review system

Efficient typesetting and proofreading procedure

Display of the result of downloads and visits, as well as the number of cited articles

Maximum dissemination of your research work

Submit your manuscript at: http://papersubmission.scirp.org/ 